\title{
The Incomprehensible Gianni Rodari
}

La poetica di Rodari: Utopia del folklore e nonsense. By Giulia Massini. Rome: Carocci, 2011. 159 pp.

L'orecchio verde di Gianni Rodari. Edited by Stefano Panzarasa. Rome: Viterbo Stampa Alernativa/Nuovi Equilibri, 2011. 226 pp.

Non solo filastrocche: Rodari e la letteratura del novecentro. By Mariarosa Rossitto. Rome: Bulzoni, 2011. 280 pp.

Lamberto, Lamberto, Lamberto. By Gianni Rodari, Trans. Antony Shugar. Illustr. Federico Maggioni. Brooklyn, NY: Melville House, 2011. 208 pp.

Standard American and British bookstores, if one can speak of standard bookstores anymore, always tend to have a large stock of the best works by national and international writers of children's literature on hand, especially their fantasy novels and fairy tales. However, none carry the numerous books written by the great Italian writer Gianni Rodari. This is rather bizarre because one cannot enter an Italian bookstore without being flooded by Rodari's diverse books. Moreover, in some European countries, such as France, Germany, Spain, and Russia, Rodari is well-known, and he even won the esteemed Hans Christian Andersen Prize before he died in 1980. This neglect in Anglo-Saxon countries is almost as incomprehensible as the incomprehensible prestige that he enjoys in Italy. How can this development be explained? And why did it come about?

Admittedly, Rodari is difficult to translate, and only a few of his books have been translated. ${ }^{1}$ But I do not believe that the reluctance of American and British publishers to translate Rodari is entirely connected to the complexity of his works. It has more to do with his socialist ideology, his unique Italian humor, and his overt sentimentalism, which can be difficult to adapt and communicate, especially in the realm of children's literature. Here, too, there is a problem because Rodari never wrote entirely for children; rather, he wrote on their behalf and constantly undermined the position and

Marvels \& Tales: Journal of Fairy-Tale Studies, Vol. 28, No. 2 (2014), pp. 424-432. Copyright (C) 2014 by Wayne State University Press, Detroit, MI 48201. 
perspective of adults through silly nonsense and fervent political beliefs. Rodari was a defiant moralist who challenged readers with humor and startling views to question the norms of their world, or as Stefano Panzarasa puts it in his unusual book Lorecchio verde di Gianni Rodari:

Critics have shed light on his capacity to present a modern moral world not through moralizing but through the activity of the imagination, either in his poetry that takes into account the experiences of futurism and surrealism, or in his fairy tales, fables and fairy-tale novels, which always reflect ideas, elements, and situations of reality. Note that he preferred more than anything a humoristic tone, or frankly comical, because it is most appropriate for communicating with today's children and also enables one to confront great problems (solidarity of people, justice, peace) without becoming too heavy. (34; translation mine)

Panzarasa's book is unusual because he came to appreciate Rodari not as a scholar but as a musician and teacher who desired to set some of Rodari's nursery rhymes and poetry to music, which he performed and continues to perform with a band in Parco Monti Lucretili outside Rome, where he works as an educator. His research led him to gather numerous documents, photos, and essays by critics and scholars that serve as a frame for the CD that accompanies his book, L'orecchio verde di Gianni Rodari (Gianni Rodari's Green Ear). Although the focus of the book is on Rodari's "ecopacifiste" ideologies, that is, Rodari's concerns for ecology and peace, it also serves as an informative introduction to Rodari's life and work. Panzarasa's book is divided into six sections: (1) "Who Was Gianni?" (twelve essays about Rodari's life); (2) "An Ear That Listens," which provides background about the origins of Panzarasa's research; (3) "Among the Benches with Gianni," which includes nine essays about Rodari's work with children in schools and other places; (4) "From Park to Park," in which Panzarasa discusses how he has used Rodari's works in parks; (5) "The Songs of the Green Ear," which includes eight essays about Rodari's nursery rhymes and poems set to music; and (6) a small anthology of Rodari's works that have a clear connection to environmental and peace movements. Most of the small chapters in these sections were written by scholars, teachers, artists, and writers who either knew Rodari or have written extensively about his work. Throughout the book Panzarasa weaves comments about the following ditty that Rodari composed a few years before his death:

The Green Ear

One day as I took the train direct to Capranica-Viterbo ${ }^{2}$

a man got on with an ear as green as an unripe tomato. 
He wasn't exactly young at all, but rather somewhat older. Except for his bright green ear, he was totally, totally in order.

I quickly moved and changed my seat to study this phenomenon from head to feet.

"Sir," I said to him, "I see you've reached a certain age, so why a green ear at this late stage?"

"Just say," he answered with courtesy, "that I've become quite old. This ear is now the only thing left from my youth-if truth be told.

This ear, a child's ear, is used to help me grasp what I canthose voices adults don't ever hear and will never understand.

I listen to what the birds say, to the words of all the trees.

I listen to the clouds that pass as well as the rocks and streams.

I understand the children when they say some things I hear, those things that seem so strange to every grown-up's ear."

That's what he said there with an ear as green as an unripe tomato on the day that I took the train direct to Capranica-Viterbo. ${ }^{3}$ (128; translation mine)

The original title of the verse in Italian is "Lorecchio acerbo," which can mean unripe ear or ear of a tender age. Throughout his works Rodari sought to liberate both children and adults from arbitrary strictures and emphasized that we must open our eyes and ears and learn to live in peace and to cultivate the environment. In this particular ditty he writes ironically against the notion that we must outgrow our "green years" and become mature and ripe. Implicit in this simple but strange incident on a train is that we have forgotten to listen to what is most important to us. Indeed, Rodari urges us to retain our "greenness." And throughout Panzarasa's songs and the short essays in his book, Rodari's sage advice continues to resonate in ways that certainly would please the famous Italian author if he were still alive.

Although Rodari might be called an environmentalist and a pacifist, he might also be "labeled" a utopian writer of nonsense nursery rhymes and fairy tales, and this is the subject of Giulia Massini's insightful study, La poetica di Rodari: Utopia del folklore e nonsense, in which she draws a revealing connection between the utopian and nonsensical aspects of Rodari's works. In the first part of her book she discusses how Rodari was, similar to Italo Calvino, strongly influenced by his experiences during World War II and the cultural and political 
devastation of Italy. In the war's aftermath Rodari, who had become what I would call a nonconformist communist, sought to develop a new language for children that would incorporate the utopian ideas that he had absorbed through reading Karl Marx, Antonio Gramsci, Calvino's Italian folktales, and works by other progressive writers who wanted to speak to the common people. Massini points out that motifs of the traditional tale "World Turned Upside Down" are present in most of Rodari's writings from the 1950s until his death in 1980. Rodari realized that utopia could not be attained simply on the basis of individual transformation and enrichment. What was needed, as Thomas More long ago pointed out, was social and political change, and Rodaris vision of utopia was derived from unusual cycles of tales that address the conception of a paradise on earth such as Atlantis, the Golden Age, Shangri-La, and Cuccagna (also known in different languages as Cokagne, Lubberland, Luilekkerland Cocagne, and Schlaraffenland, all of which connote the land of milk and honey). As we know, utopia means nowhere. It is not a real but rather a fictional and moral land. It has been created out of all sorts of intentions. Some Cuccagna tales envision a perfect government, which does not exist because of the corrupt nature of people in the world and also cannot exist. Rodari playfully sought to find the right tune, tone, and humor to explain to children (and adults) why we failed to do the impossible that he thought was possible to accomplish.

In effect, this is why Rodari became so fond of the filastrocca, which can be translated as a nursery rhyme, ditty, yarn, or limerick. Massini spends the second part of her book explaining how Rodari virtually introduced the AngloSaxon tradition of Lewis Carroll, Edward Lear, A. A. Milne, and other writers into the field of Italian children's literature, while also using folk and fairy-tale motifs. Rodari's linguistic experiments were generally geared to raise political consciousness. For instance, his use of the binominal fantastic (a combination of two arbitrarily chosen nouns with an arbitrarily chosen preposition) was intended to create a poem, rhyme, story, or even a novel that would at first reading not seem to make any sense. Yet its meaning would be found in nonsense that always had a deeper sense created out of the play with words to liberate the imagination. Here is one example:

Speranza

S'io avessi una botteguccia

fatta d'una sola stanza

vorrei mettermi a vendere

sai cosa? La speranza.
Hope

If I had a very small shop

made only of one room, do you know what I'd begin to sell? It would be hope. 
"Speranza a buon mercato!"

Per un soldo ne darei

ad un solo cliente

quanto basti per sei.

E alla povera gente

che non ha da campare

darei tutta la mia speranza

senza farla pagare.
"Hope for sale! Hope cheaply!"

I'd give it for a penny

just to one client enough for six people.

As to all the poor people who have nothing to live on I'd give all of my hope without making them pay.

My prose rendition does not do justice to Rodari's play of words such as botteguccia, which might also be a barrel full of hope. I have chosen this small poem to illustrate briefly how Rodari worked off two nouns (shop and hope) that do not seem to fit together. The nonsense (the sale of hope) is minimal, whereas the political and utopian aspects are clear. Massini presents many more examples that demonstrate how invested Rodari was in his role as writer and provocateur, who sought to animate children to think for themselves and out of the box - and to provide hope in a hopeless world.

Mariarosa Rossitto takes a much different approach to Rodari's works that does not contradict Massini's study but complements it. Her significant study's title, Non solo filastrocche: Rodari e la letteratura del novecento (Not Only Nursery Rhymes: Rodari and Twentieth-Century Literature), indicates her intention to study Rodari as more than a writer for children. Indeed, she clearly seeks to raise his reputation, so to speak, and regard him as a writer who transcends the epithet "children's literature author." Rossitto divides her book into five chapters. The first two deal with Rodaris life and his literary background. Although Rodari never attained any kind of university degree, his reading was vast and he was a sophisticated thinker, even though he liked to think of himself as a kind of dilettante. Rossitto shows that he had a great interest in all the avant-garde movements of his time and constantly experimented with surrealist techniques. In the last three chapters of her book, she focuses on three major works, Le Novelle fatte a macchina, C'era due volte il barone Lamberto ovvero I misteri dell'isola di San Giulio, and Il gioco dei quattro cantoni, to explore their complex styles and themes. Here I would like to focus mainly on C'era due volte il barone Lamberto ovvero I misteri dell'isola di San Giulio (Once upon Two Times the Baron Lamberto, or The Mysteries of the Island of San Giulio) before discussing the recent English translation, Lamberto, Lamberto, Lamberto.

As Rossitto explains, Rodari told this tale many times to youngsters and published a couple of shorter versions before he transformed the story about the Baron Lamberto into a bizarre fairy-tale novel that has aspects of surrealism 
and magic realism. And of course there is plenty of nonsense, and one could even call the novel a gentle mock fairy tale. The story takes place in northern Italy on Lake Orta, not far from where Rodari himself was born and raised. The protagonist is the 93-year-old Baron Lamberto, one of the richest men in the world, who owns twenty-four banks and is suffering from twenty-four diseases. He lives all alone in a huge mansion situated on the island of San Giulio in the middle of Lake Orta. He is faithfully looked after by his formal butler, Anselmo, and he spends his winters vacationing in his mansion near the pyramids in Egypt. In the winter of his ninety-third year, when he is complaining about all his illnesses, he meets a fakir, who reveals to him that if his name is repeated constantly every day, he will recover from his illnesses and become young once again, if not immortal. So Lamberto immediately returns to his villa on the island of San Giulio and hires six people who are paid extremely high wages to repeat his name, "Lamberto, Lamberto," day and night. They are not told why they should do what they are told to do. They live "encased" in the attic and are supplied with anything and everything they desire. When they take breaks every now and then, they speculate about their task and why they are repeating Lamberto's name. In the meantime, Lamberto begins to turn young and becomes healthy. While he undergoes this transformation, his decadent nephew Ottavio visits him because he has run out of money and expects his uncle to die soon and leave him a fortune. When he discovers that Lamberto is as healthy as an ox, he tries to kill him but bungles the job. At one point, when Ottavio leaves the island to go to the town of Orta so he can find sleeping pills to put the six speakers to sleep and stop Lamberto's rejuvenation, the villa is invaded by twenty-four bandits who take Lamberto hostage and demand millions of dollars as ransom; otherwise, they will kill him. What follows are days of absurd negotiating with the mayor and twenty-four of Lamberto's bankers, who fly to Orta and are unwilling to give money to the bandits because they cannot recognize the "young" Lamberto from pictures. Indeed, he has changed greatly in appearance. Word about the hostage taking spreads, and hundreds of curious people (including journalists and tourists) appear at Orta because Lamberto is so famous. The negotiations with the bandits continue to falter even when they send a finger and ear of Lamberto because the bank directors refuse to recognize him or his handwriting. (The parts of Lamberto's body always grow back.) Meanwhile, Ottavio manages to put the six speakers to sleep, and without their chanting his name, Lamberto becomes old and dies, causing the twenty-four bandits to flee the mansion in an air balloon. Without a hostage, no money! To their dismay, the balloon crashes, and they are captured by boy scouts and arrested. At the same time, the "dead" Lamberto is transported on a barge from the island to Orta, and as he lies in the coffin, the hundreds if not thousands of people on shore start calling out his 
name, "Lamberto, Lamberto," and thanks to the chorus of voices, he regains his life and rises.

When Lamberto is happily brought back to his mansion, the six speakers wake up from the sleeping pills and finally descend from the attic to confront Lamberto. Ottavio flees, and the speakers learn for the first time why they were hired and how they have a certain power over Lamberto. The leader of the group, Delfina, a pretty young woman, whom Lamberto would like to marry, refuses because she and the others feel exploited, and so they use their power to speak and transform Lamberto into a 13-year-old. The story ends without a happy ending — that is, there is no wedding, and we do not learn anything about Lamberto's future. However, there is an epilogue in which Rodari encourages readers, if they are dissatisfied with the ending, to write their own.

I have written this short summary of Rodari's novel to demonstrate, as Rossitto does, that Rodari's works depend on a complicated series of nonsensical and unanticipated events and actions that cause readers constantly to stop and ponder why everything appears to be so absurd, if not grotesque. Rodari was not interested in psychology or carefully drawn characters. Indeed, the characters are often caricatures or stereotypical people who represent social classes in conflict with one another. Class conflict is central to most of Rodari's writings, and he always reveals a tender spot for oppressed people. So, in C'era due volte il barone Lamberto, Rodari's "heroine" is Delfina, and he also portrays other servants warmly-the boatman, the butler, the five other speakers-whereas the bankers and mayor are greedy and stupid bureaucrats, Ottavio is a conniver, the journalists are paparazzi, and Lamberto himself is egocentric and indifferent to the world. Rodari does not use satire in his depictions of character types. Rather, he is drawn to farce to expose their contradictions as they seek money, power, and fame. Rossitto's thorough analysis and interpretation of the novel focuses on the theme of rejuvenation, or how we all desperately want to avoid old age and seek to remain young. She points to Rodari's bad health and complaints about his sicknesses in 1977 and 1978. There is no doubt that the novel can be viewed as a light comic meditation on aging and a hilarious self-critique. However, such an emphasis ignores Rodari's radical experimentation with the fairy-tale genre and his emphasis on the vanity and futility of powerful people who cannot control their own destiny no matter how much money they have. Rodari inverts the fairy tales and folktales that deal with the pursuit of the water of life or the philosopher's stone to show how meaningless and worthless such a pursuit is. The beginning of his title alone, "once upon two times," alerts readers that Rodari will turn the traditional folk- and fairy-tale scheme into a tale that needs to be told 
twice and that will occur many times. How the second telling might evolve will depend on the imagination of readers.

In the Melville House publicity letter (October 18, 2011), the editors announce: "Based on the Red Brigades' kidnapping and murder of Aldo Moro, Lamberto, Lamberto, Lamberto is a fable for children and adults: a story of life, death, and resurrection-in the grand tradition of Exupéry's The Little Princeand is supplemented with thirty black and white illustrations of fantastic, memorable characters." Such a statement demeans Rodari's work. First of all, there is no mention in Rodari's works and letters of the Red Brigades or his intention to draw a parallel to the murder of Aldo Moro. Second, as other critics and I have shown, this work is not a fable. Nor can it be compared in any way to the solipsistic Little Prince. It is impossible to understand or even translate C'era due volte il barone Lamberto without grasping Rodari's political agenda to transform genres with subtle comic apprehension and comprehension of the habitus of people who are continually placed in situations that reveal their absurdity and the absurdity of life. The present translation of C'era due volte il barone Lamberto is good and dependable but lacks the luster of the original. Moreover, it lacks the original title, which might have animated the translator to capture Rodari's jovial spirit and nostalgia when he returned to his native province to do research and painted a surrealistic picture of what was happening to Italians in the late 1978 eclipse of the revolutionary movements of the 1960s. ${ }^{4}$ The question Rodari raised at the end of C'era due volte il barone Lamberto is whether Lamberto and Italians deserved a second chance to live their lives differently.

Jack Zipes

Professor Emeritus, University of Minnesota

\section{Notes}

1. Here is a list of Rodari's books in English. All of them are out of print:

(a) Telephone Tales. Trans. Patrick Creagh. London: Harrap, 1965. (A selection of stories from Favole al telefono)

(b) The Befana's Toyshop: A Twelfth Night Tale. Trans. Patrick Creah. London: Dent, 1970. (Translation of La freccia azzurra)

(c) A Pie in the Sky. Trans. Patrick Creah. London: Dent, 1971. (Translation of La torta in cielo)

(d) Tales Told by a Machine. Trans. Sue Newson-Smith. London: Abelard and Shulman, 1976. (A selection of stories from Novelle fatte a macchina)

(e) The Grammar of Fantasy: An Introduction to the Art of Inventing Stories. Trans. Jack Zipes. New York: Teachers \& Writers, 1990. (Translation of Grammatica della fantasia) 
(f) Tales to Change the World. Trans. Jack Zipes. Illustr. Robert Mason. Lincoln: Caseroom Press, 2008. (A collection of six stories from different collections)

2. Capranica is a small town in the province of Viterbo, about 45 miles northwest of Rome. The diretto is a local train that makes many stops.

3.

Orecchio Acerbo

Un giorno sul diretto Capranica-Viterbo

vidi salire un uomo con un orecchio acerbo.

Non era tanto giovane, anzi era maturato

tutto, tranne l'orecchio, che acerbo era restato.

Cambiai subito posto per essere vicino

a potermi studiare il fenomeno per benino.

Signore, gli dissi, dunque, lei ha una certa età

di quell'orecchio verde che cosa se ne fa?

Rispose gentilmente: Dica pure che sono vecchio

di giovane mi è rimasto soltanto quest'orecchio.

È un orecchio bambino, mi serve per capire

le voci che i grandi non stanno mai a sentire.

Ascolto quel che dicono gli alberi, gli uccelli, le nuvole che passano, i sassi, i ruscelli.

Capisco anche i bambini quando dicono cose che a un orecchio maturato sembrano misteriose.

Così disse il signore con un orecchio acerbo quel giorno, sul diretto Capranica-Viterbo.

4. Melville House could have, or perhaps should have, published Rodari's preface, "Questa Storia," in the second edition of C'era due volte il barone Lamberto, published by Einaudi in 1979 in the series "Lettura per la scuola media" and illustrated by Paola Rodari, his daughter. A translation of the preface would have helped English-speaking readers understand some of Rodari's intentions. 